\title{
Revenue Diversification Strategies for Non-Governmental Organizations
}

Emil CRIȘAN ${ }^{1}$

Mădălina DAN ${ }^{2}$

Abstract
Nowadays, NGOs have an important place in our society, but unfortunately
almost every NGO is struggling financial issues. The purpose of this paper is to
analyze the main strategies NGOs have for revenue diversification, as a path to
financial sustainability. This article focuses on Romanian NGOs and its main goal is to
identify how NGOs choose their revenue diversification strategy. The empirical
research consists in two case-studies, the focus being on identifying the revenue
streams two NGOs have chosen. The main finding is that the choice of revenue
strategies is related to the context each NGO has, context that can be described
considering their life cycle, specialization, place within local and regional areas and
the recent lessons each NGO has learned concerning specific revenue strategies. This
study successfully defines the main concerns and limitations fundraising has and also
contributes to academic debate about how to solve these issues.

Keywords: non-governmental organizations, revenue diversification, financial sustainability, Romania, case-study

JEL classification: L31, G31.

DOI: $10.24818 /$ RMCI.2018.1.31

\section{Introduction}

As for any for profit organization, financial resources are one of the most important resources while managing NGOs, together with human resources and operational infrastructure (Cace et al., 2012). NGOs all over the world are struggling financial issues, the scarcity of financial resources being one of the major causes for the structural adjustments these companies face every year. NGOs organize their activities through the usage of projects. Even the success of helping others is great, running a new project is very often questioned by the existence of money. For example, Romanian NGOs have changed their business model once the financing opportunities related to the European Union structural funds, allocated

\footnotetext{
${ }^{1}$ Emil Crișan, Babeș-Bolyai University, Cluj-Napoca, emil.crisan@econ.ubbcluj.ro

${ }^{2}$ Mădălina Dan, Babeș-Bolyai University, Cluj-Napoca, madalina.dan@econ.ubbcluj.ro
} 
between 2007 and 2013, have appeared. It should be mentioned that this type of funding is often for a short period of time and it's not a stable source (Ciucescu, 2011).

The studies about the revenues of NGOs have focused very much on private donations, which are one of the many streams of NGOs revenue, and this source provide, on average, approximately $20 \%$ of income (Boris and Steuerle, 2006). The underlying objective of this paper is to study alternative revenue strategies NGOs have and to see how they could achieve financial sustainability by combining multiple sources of revenue. Achieving financial sustainability is a real challenge for organizations because their financial situation is very unstable and the revenue depends on their projects, ones which present a limited potential for continuity (Ciucescu, 2009).

The methodology used to reach our objective is divided into two parts:

- Within the first part of the paper a brief overview of relevant literature is performed. It is essential to identify the alternative revenue strategies NGOs have, strategies that shall be further used in the presentation of the two case studies revealed later in the empirical research section.

- The second part is related to two case studies about Romanian NGOs. A short history of each organization and their financing strategy over the years are presented. The data was collected using the data available online, while the information obtained is used to establish whether the organizations are financially sustainable or have the potential to become. Also, using these case studies, another goal is to identify the key contributing factors for achieving financial stability (Abdelkarim, 2002).

\section{Literature review}

\subsection{Revenue strategies for NGOs}

Non-governmental organizations have different types of activities in fields like: humanitarian, educational, health care, public policy, human rights, environmental etc. These activities are by nature „unprofitable” (Viravaidya and Hayssen, 2001). These organizations are used to rely very much on others for covering their financial needs, focusing mainly on donations. Nowadays, this strategy isn't enough to fulfill the growing needs and increasing costs these organizations face.

The financial issues affect organizations active both in poor or rich countries, and both small or big organizations. All NGOs are struggling with unlimited needs, having available limited resources (Viravaidya and Hayssen, 2001). NGOs can obtain funds for their activities from a variety of sources, but there are three main funding strategies. The first strategy is the most common: fundraising campaign to attract donations from individuals or corporations. Another strategy and source might be applying grants proposals from the

32 Review of International Comparative Management Volume 19, Issue 1, March 2018 
government or from other institutions. A more controversial strategy is to perform economic activities that will create revenues that can be further used for the main goal of the NGO (Froelich, 1999).

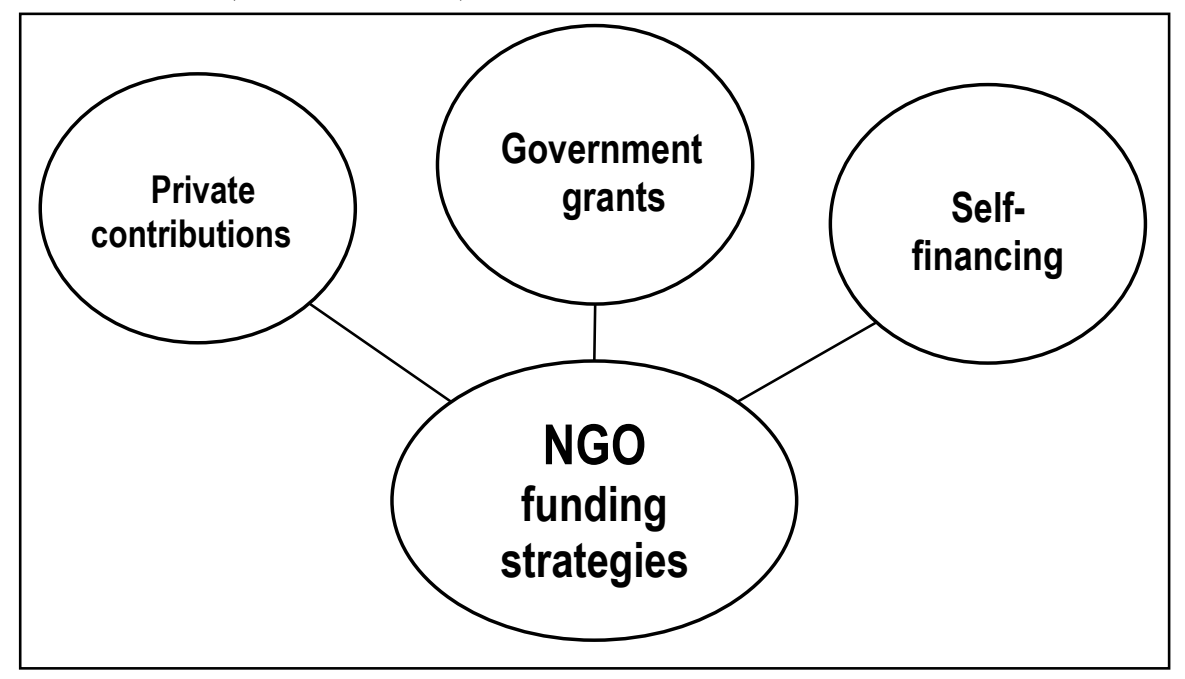

Figure 1: NGOs Funding Strategies

Private contributions, individual or corporate donations, foundation grants and sponsorship, are one of the main sources of funding of NGOs. Through donations, a donor gives to a donee money or goods without waiting for something in return. In fact, attracting donation activities can be difficult firstly because of the restrictive laws, and secondly due to the fact that some NGOs don't know how to attract donors and how to promote their projects. Usually, donations can be used at NGOs discretion, but in some cases the organizations have to report every step they take and they have to take into consideration some conditions imposed by the donor. Donations can be in many forms. A company can donate goods and services, it can send people to volunteer, or it can donate money, the latest being probably the most used form of donation. The same as income from private contributions, corporate contributions generate many constraints that impact the processes and the structure of NGOs. Also, dependency on private donations is responsible for goal displacement, NGOs being very often forced to choose those areas that donors are interested in (Froelich, 1999).

Government grants may be more predictable and stable toward other funding sources (Froelich, 1999), so the revenue volatility has a low level, but they have a big disadvantage: bureaucratic demands. An NGO which depends on government grants risks to have difficulties in attracting private contributions due to the bureaucratic restrictions imposed by the government within the already approved grants (Brooks, 2000). Goals adaptation is not that serious like in the case of private contributions, instead the funds provided by the government are usually directed to facilitate some groups ignored by private contributors. Also, an 
organization dependent on government grants is very vulnerable to economic crisis (Feiock and Jang, 2009), NGOs' financing being one of the first costs one government could diminish during challenging economic periods.

However, there are few examples of NGOs founded in accordance with available government funds (Lipsky and Smith, 1989).

Self-financing is related to commercial activities performed by NGOs and generating revenues that can be further used for the main goal of the NGOs. These two categories include revenues like: membership fee, income from renting out, income from investments and sales of goods and services (Pavlina and Marta, 2012). NGOs that succeed to generate their own revenue by the above means, become less dependent on other financing sources. Although commercial activity leads to financial independence for NGOs, it entails the risk that the social mission is downturned on the second place, while revenues and profits become the most important mission for the organization (Froelich, 1999). The positive fact is that goal displacement is weak in this case, because the commercial activity is done in concordance with NGOs plans and projects. However, there are also NGOs that have chosen a commercial activity totally unrelated to the main mission of an NGO, raising the question whether the NGO exists anymore or we deal with an economic organization that also performs some corporate social responsibility projects. The debate can be further extended on the limits NGOs should have in financing their activities. There are countries that limit the activities that can be done in a NGO, while in countries like Romania NGOs can also become real economic players and this way they can attract relevant income for their main mission.

A comparison between the three strategies is further presented in table 1.

Table 1: Revenue Strategy Profiles

\begin{tabular}{|l|l|l|l|}
\hline & \multicolumn{1}{|c|}{$\begin{array}{c}\text { Private } \\
\text { Contributions }\end{array}$} & \multicolumn{1}{|c|}{$\begin{array}{c}\text { Government } \\
\text { Funding }\end{array}$} & Self-financing \\
\hline Revenue volatility & High & Low & Moderate \\
\hline $\begin{array}{l}\text { Goal displacement } \\
\text { effects }\end{array}$ & Strong & Moderate & Weak \\
\hline Process effects & Formalization & $\begin{array}{l}\text { Formalization, } \\
\text { standardization }\end{array}$ & Rationalization \\
\hline Structure effects & $\begin{array}{l}\text { Professionalized } \\
\text { administration }\end{array}$ & $\begin{array}{l}\text { Professionalized } \\
\text { bureaucracy }\end{array}$ & $\begin{array}{l}\text { Professionalized } \\
\text { business forms }\end{array}$ \\
\hline
\end{tabular}

\subsection{The revenue diversification strategy}

The concept of revenue diversification appeared in a study about the Modern Portfolio Theory (Markowitz, 1952) in which is explained the risk-reward relationship: the bigger are portfolio return expectations, the bigger gets the volatility of the portfolio. This rule leads to an optimal portfolio that will both maximize expected returns and minimize variance, but this is very difficult to

$34 \quad$ Review of International Comparative Management

Volume 19, Issue 1, March 2018 
obtain in real life situations, because these two characteristics are specific to different portfolio types. So, an investor has to choose between assuming higher risk with the goal to maximize their expected revenues, or to choose to gain less but also to minimize variance (Carroll and Stater, 2008). Diversification is the key of success in obtaining a performing portfolio.

As time went on, Modern Portfolio Theory has been adapted for governments and NGOs to use it for raising capital. Although NGOs strategies of raising capital is different between organizations, revenue diversification is applicable with the purpose of reducing revenue volatility (Froelich, 1999). So, when designing a revenue portfolio, NGOs managers should consider all sources types and strategies: private donations from individuals or companies, government grants and self-financing, and will assess both the expected return and the financial risk for each source (Jegers, 1997).

Over the years, many research has been done about the impact of revenue diversification over NGOs' activity. Some studies have demonstrate that revenue diversification is positively correlated with financial health (Chang and Tuckman, 1994). Another study reveals that a high level of diversification reduces the likelihood that an NGO will cut off the budget for a program (Trussel, 2002). A high level of diversification also decreases the chances NGOs have to become bankrupted (Hager, 2001).

Revenue diversification brings new concerns and greater complexity for NGOs (Froelich, 1999), but it also decreases revenue volatility and contributes to financial stability over time (Caroll and Stater, 2008).

\section{NGO revenue strategies case studies}

\subsection{Methodology}

The empirical research of this study is based on the analysis of two NGOs from Romania: Foundation of Peoples' Development (FDP- http://www.fdpsr.ro/) and Foundation Princess Margareta of Romania (FPM - https://www.fpmr.ro/). These two Romanian case-studies were developed based on the information available online on their websites. The goal of the research was to identify their revenue strategies. In order to identify this element, several details were analyzed: services and history, projects and other revenue streams. Based on this information, a context approach is used for analyzing their financing activity.

\subsection{Case study 1 - FDP Association- Protagonists in education}

\section{History}

FDP is an NGO founded in 1996 with the help of Italian founders, having its headquarters in Bucharest and three subsidiaries in Arad, Cluj-Napoca and Dâmbovița. This organization offers socio-educational opportunities and professional integration of people from vulnerable groups. 
Social and assistance services offered:

- school support;

- recreational-educational activities;

- psychological counselling;

- information and counseling to raise awareness of the importance of education;

- training staff in different areas;

Employment incentive services:

- information, guidance and professional counselling;

- training;

- tutoring;

- professional mediation.

\section{Projects and revenue streams}

The FDP has many underway projects and completed projects. Each project is described on the organization's website and there is mentioned: duration, budget, location, objectives, beneficiaries, financing parties.

Public-private partnership for autonomous families is a project through which it has developed a counselling and support center for parents and child. This project was funded through SEE 2009-2014 grants, through the NGO fund for Romania.

Active partnerships for school inclusion of children with special educational requirements is another developed project and is funded with the financial support of the RO10-CORAI Program, which is funded by SEE 20092014 grants.

PRISM: Preventing, redressing and inhibiting hate speech in new media is a project held between December 2014 and June 2016 and was funded by the European Commission and involves partners from four other countries: France, United Kingdom, Italy and Spain.

Remote support is a multiannual program which objective is to prevent school dropout. This program was supported by private donors from Italy trough the AVSI Organization.

Active partnerships for the development of the social economy was a threeyear project financed by European Social Fund through the Sectoral Operational Program Human Resources Development 2007-2013.

Besides these mentioned sources, the FDP has many partners: companies, government institutions, organizations and federations, and also individual sponsors.

36 Review of International Comparative Management Volume 19, Issue 1, March 2018 


\subsection{Case study 2 - Foundation Princess Margareta of Romania (FPMR)}

\section{History}

Founded in 1990 by Her Royal Highness Princess Margareta of Romania, together with her father, His Majesty King Mihai I, this foundation has developed over the years many sustainable projects in the education field, community development, health and culture. The objective of FPMR is to help vulnerable people: elderly, abandoned children and needy families. From 1990 until today, in 27 years of activity, the foundation helped thousands of people and invested 12 million euros in Romania.

\section{Projects and revenue streams}

The Special Children's Fund is a national social assistance and education program to support children in very difficult life situations.

The elderly phone is free phone line for elderly where they can find someone who gives them an answer and a good word when they feel lonely.

The Young Talents Program supports and promotes talented young artists from low-income families who can't afford to develop their talent. This program is funded by The Royal Charity Concert. The money collected from ticket sales will be used to award scholarships for young artists with financial difficulties. Also, for this project they have three important partners.

Besides these projects, the FPMR has many others. On their website is a section for those who want to support the foundation by different means. Campaign $2 \%$ consists of donating $2 \%$ of the income tax by completing a form. Also, one can donate by signing up as a fundraiser on a specific website, and then mobilizing their friends and family to donate to the cause. Another option is Monthly Donor, which means donating a monthly fixed amount. For companies, an option for sponsorship is to donate $20 \%$ of the income tax an $0,5 \%$ of turnover through a sponsorship contract.

Earnings in 2016: sponsorships from companies - 2,782,218 lei (86,6\%), individual donors - 257,729 lei (8\%), DGASPC Grant - 171,960 lei (5,4\%).

\subsection{Discussions}

The two-presented case-studies refer to two different organizations. One has a greater visibility at national level (FPMR), a longer history, and based on the important support ensured by the Romanian Royal family, even more financial resources and projects. FDP was developed and managed by hard-working persons who were able to create a 20 -years active NGO in the Romanian challenging environment. It is obvious that FPMR has greater access to donors, while FDP had to diversify its strategy and to attract as many external grants as possible. Even though, they have common strategies, such as: the $2 \%$ Campaign, the possibility to donate directly on the site once or monthly. Still, FDP is oriented to access 
European Funds, accessed through various programs, while the FPMR focuses on private donations.

It can be easily observed that revenue strategies both NGO choose are related to multiple factors, factors that all together create the environment where each NGO performs:

- The members of the NGO and especially the founders influence the access to important donors. In the case of FPMR, it is important to observe that the Romanian Royal family was able to attract many important people and corporations as donors;

- The Romanian state can influence the existence of a small part of every NGO financial resources through the $2 \%$ Campaign and through the tax deduction program. Both NGO benefit from these two programs. It is a part of their revenues covered by government programs;

- The lack of revenue alternatives forces NGOs to access external grants from different institutions, with all the associated risks. FDP has probably developed specific skills and competences needed to access European Union funds, FEE Funds etc. Though these grants force NGOs to adapt their mission, basically to temporarily extend the people that are the final beneficiaries of NGOs activities, NGOs sometime have no alternative but to play this game. FDP, in this case, has developed the skills, the competences, but has also extended their mission. The question is what is going to happen when the external funds finish and no grants are further offered.

\section{Conclusions}

The choice NGOs make regarding their revenue strategy is basically related to the context they have. If they are able to ensure enough donations in order to attain their mission, they would probably apply for this strategy, combined with the revenues provided by the state programs. If these donations are not sufficient, the next strategy would be to apply for external grants. These would affect the main mission of the NGO, but would still be able to ensure sufficient funding in order to meet the initial and the extended mission. Unfortunately, we did not reveal within the current research one Romanian NGO that would choose selffinancing for its activity. These is an element that can be further analyzed.

To succeed with their resource diversification strategies, NGO managers need to find a balance between potential benefits and effects of different strategies (Khieng, 2014). Each revenue strategy has its opportunities and advantages, but also owns constraints and pressure that could affect the NGO independence. In order to reduce their vulnerability to income volatility and the influence of donors, NGOs have gone from a single source of funding to revenue diversification (Froelich, 1999).

Further research is needed concerning the evolution of revenue strategies over the years for different NGOs, influenced by economic and political changes in the last decade in Romania and the effects of NGOs different choices in diversifying sources of funding.

$38 \quad$ Review of International Comparative Management Volume 19, Issue 1, March 2018 


\section{References}

1. Abdelkarim, N., 2002. The Long-Term Financial Sustainability of the Palestinian NGO sector: An Assessment. Study Commissioned by the Welfare Association Consortium.

2. Boris, E.T. and Steuerle, C.E., 2006. Scope and dimensions of the nonprofit sector. The nonprofit sector: A research handbook, pp. 66-88.

3. Brooks, A.C., 2000. Public subsidies and charitable giving: Crowding out, crowding in, or both?. Journal of Policy Analysis and Management, pp. 451-464.

4. Cace, S., Arpinte, D., Cace, C. and Cojocaru, D., 2012. Financial Resources Management--Factor of Sustainable Development of the NGOs Implementing Social Economy Activities. Transylvanian Review of Administrative Sciences, (36).

5. Carroll, D.A. and Stater, K.J., 2008. Revenue diversification in nonprofit organizations: Does it lead to financial stability?. Journal of public administration research and theory, 19(4), pp. 947-966.

6. Chang, C.F. and Tuckman, H.P., 1994. Revenue diversification among nonprofits. VOLUNTAS: International Journal of Voluntary and Nonprofit Organizations, 5(3), pp. 273-290.

7. Ciucescu, N., 2012. Financial Resources of NGOs. Studies and Scientific Researches. Economics Edition, (16-17).

8. Feiock, R.C. and Jang, H.S., 2009. Nonprofits as local government service contractors. Public Administration Review, 69(4), pp. 668-680.

9. Froelich, K.A., 1999. Diversification of revenue strategies: Evolving resource dependence in nonprofit organizations. Nonprofit and voluntary sector quarterly, 28(3), pp. 246-268.

10. Hager, M.A., 2001. Financial vulnerability among arts organizations: A test of the Tuckman-Chang measures. Nonprofit and Voluntary Sector Quarterly, 30(2), pp. 376-392.

11. Jegers, M., 1997. Portfolio theory and nonprofit financial stability: A comment and extension. Nonprofit and voluntary sector quarterly, 26(1), pp. 65-72.

12. Khieng, S., 2014. Funding mobilization strategies of nongovernmental organizations in Cambodia. VOLUNTAS: International Journal of Voluntary and Nonprofit Organizations, 25(6), pp. 1441-1464.

13. Lipsky, M. and Smith, S.R., 1989. Nonprofit organizations, government, and the welfare state. Political Science Quarterly, 104(4), pp. 625-648.

14. Markowitz, H., 1952. Portfolio selection. The journal of finance, 7(1), pp. 77-91.

15. Pavlína, H. and Marta, L., 2012. Qualitative Risk Assessment of Financial Resources of NGOs. Littera Scripta, (2), pp. 43-52

16. Trussel, J.M., 2002. Revisiting the prediction of financial vulnerability. Nonprofit Management and Leadership, 13(1), pp. 17-31.

17. Viravaidya, M. and Hayssen, J., 2001. Strategies to strengthen NGO capacity in resource mobilization through business activities (p. 1). UNAIDS Best Practice Collection: PDA and UNAIDS joint publication. 